\title{
Factors affecting plasma biochemistry parameters and physical condition of Osprey (Pandion haliaetus) nestlings
}

\author{
Roberto Muriel - Daniel Schmidt - Cecilia P. Calabuig • \\ Juan Patino-Martinez $\cdot$ Miguel Ferrer
}

\begin{abstract}
We assessed the normal values for 15 blood plasma biochemistry parameters and three indices of body condition (IBCs) in free-living Osprey (Pandion haliaetus) nestlings in Brandenburg (Germany). Values were compared with those of other raptors, and possible sexual and age-related differences were examined. In addition, we looked for possible relationships of habitat quality (measured in terms of foraging conditions and human disturbances) to nestling nutritional condition and productivity. Female nestlings showed higher mean urea levels and lower glucose values than males, which could be related to higher growth rates and nutrient demand of females at the end of the nestling period. Seven parameters also showed variation with age, probably relating to increasing body mass, metabolic rates, and physical activity during the pre-fledging stage. Conversely, the IBCs showed poor correlations with selected nutritional parameters, probably due to the homogeneously acceptable nutritional conditions of the nestlings. Finally, we found that Ospreys did not seem to adjust initial parental investment in relation to habitat quality, since productivity was not affected by habitat indicators. However, in large broods, but not in small ones, nestling nutritional condition improved as
\end{abstract}

R. Muriel $(\varangle)$ C C. P. Calabuig · J. Patino-Martinez · M. Ferrer Department of Ethology and Biodiversity Conservation, Estación Biológica de Doñana (CSIC), C/Americo Vespucio s/n, 41092 Sevilla, Spain

e-mail: muriel@ebd.csic.es

D. Schmidt

NABU-Centre for Bird Protection Mössingen, Ziegelhütte 21, 72116 Mössingen, Germany foraging conditions improved. These results suggest that females that are in better physical condition seem to produce more and better nourished nestlings in better foraging conditions.

Keywords Habitat quality - Index of body condition . Nutritional condition · Osprey · Pandion haliaetus . Plasma biochemistry

\section{Zusammenfassung}

Einflussfaktoren auf biochemische Blutplasma-Parameter und körperliche Kondition nestjunger Fischadler (Pandion haliaetus)

Wir beurteilten Normalwerte für 15 biochemische Blutplasma-Parameter und drei Indizes für die Körperkondition (Indices of Body Condition-IBCs) bei freilebenden nestjungen Fischadlern (Pandion haliaetus) in Brandenburg (Deutschland). Die Werte wurden mit denen anderer Greifvogelarten verglichen und mögliche geschlechts- und altersabhängige Unterschiede wurden untersucht. Zusätzlich haben wir denkbare Zusammenhänge zwischen der Habitatqualität-gemessen anhand der Lage von Gebieten der Nahrungssuche und anhand menschlicher Störungund dem Ernährungszustand der Nestlinge sowie der Reproduktion untersucht. Weibliche Nestlinge zeigten höhere Harnstoff-Durchschnittswerte und geringere GlukoseWerte als männliche, was mit einer höheren Wachstumsrate und einem höheren Nährstoffbedarf bei den jungen Weibchen gegen Ende der Nestlingsperiode zusammenhängen kann. Sieben Parameter zeigten Veränderungen abhängig vom Alter, wahrscheinlich im Zusammenhang mit der zunehmenden Körpermasse, mit dem höheren Metabolismus und mit der steigenden körperlichen Aktivität während der 
Phase kurz vor dem Flüggewerden. Umgekehrt zeigten die IBCs geringe Korrelationen mit ausgewählten Parametern bezüglich der Nährstoffversorgung, wahrscheinlich aufgrund angemessener und gleichmäßiger Versorgung der Nestlinge. Schließlich fanden wir, dass Fischadler ihre ursprünglichen elterlichen Investitionen vermutlich nicht der Habitatqualität anpassten, da die Reproduktion nicht von den Habitateigenschaften beeinflusst wurde. Jedoch verbesserte sich die Nährstoffversorgung in großen Bruten mit besseren Bedingungen zur Nahrungssuche, nicht aber in kleinen Bruten. Unsere Ergebnisse legen es nahe, dass Weibchen mit besserer Körperkondition mehr und besser ernährte Jungvögel hervorbringen, insbesondere unter besseren Bedingungen für die Nahrungssuche.

\section{Introduction}

Studies of plasma biochemistry and hematology are important for veterinary diagnoses of wild and captive animals, but also in a wide range of work performed across many disciplines, such as scientific research into animal ecology or the management of endangered species. Plasma levels of biochemistry parameters provide valuable information on the physiological condition of the animal of interest, which is related to individual quality and therefore various other related factors, including survivorship, fecundity, spatial ecology, evolutionary ecology, etc. (Ferrer 1993). Since the 1970s, blood parameters have increasingly been used as physiological indicators, body condition indices have been developed, and reference values have been assessed for many species (e.g., Johnson et al. 1985; Ferrer et al. 1987; Dujowich et al. 2005). However, most of these studies have dealt with domestic or captive animals; few of them provided chemistry values for wild species. In the last 20 years, studies have also focused on the influence that factors such as gender, age, circadian and seasonal rhythms, reproductive stage, diet, body condition, genetics, fasting, stress, pathological disorders, and captivity have on physiological condition (e.g., GarcíaRodríguez et al. 1987a; Dobado-Berrios et al. 1998; Tilgar et al. 2004; Alonso-Álvarez 2005; Jerzak et al. 2010). However, despite the fact that the availability of biochemical indicators is increasing, there is still a lack of integration of this information as normal explicative cofactors into comprehensive analyses of biological and ecological patterns, and very few studies have applied this integrative approximation of blood chemistry, despite its utility (e.g., natal dispersal and regulation of postfledging period; Ferrer 1992a, b). Therefore, reference blood chemistry values of wild animals are required so that the effects of such factors on blood parameters can be interpreted, and in order to incorporate general physiology into ecological research and management actions.

The Osprey (Pandion haliaetus) is a cosmopolitan bird of prey with an ecology that has been widely studied from different points of view: development, breeding, migration, population dynamics, etc. (e.g., Poole 1989; Saurola 1997; Kjellén et al. 2001). Moreover, the Osprey has received much attention in toxicological and biomagnification studies, since it is considered a top-consumer species in aquatic ecosystems and is specialized for a fish diet (Steidl et al. 1991; Weber et al. 2003; Toschik et al. 2005; Grove et al. 2009). Despite this, there is a surprising lack of information about plasma biochemistry or hematology in Osprey, and no published values for blood parameters are available.

Some studies have analyzed the influence of environmental characteristics on breeding performance of Ospreys (e.g., Van Daele and Van Daele 1982; Löhmus 2001; Harmata et al. 2007). These works have shown that breeding Ospreys seem to adjust parental investment during the nestling and post-fledging periods in relation to habitat foraging quality, but not during the pre-laying period. However, there is little information on nestling quality in relation to habitat characteristics and the corresponding adjustment of parental care. Furthermore, the few studies that have examined variation in nestling body condition using growth rates and morphological clues failed to find relations with habitat quality (e.g., Steeger and Ydenberg 1993). Thus, appropriate plasma biochemical parameters could be used to examine the potential relationships between habitat and nestling body condition using a more straightforward approach.

Therefore, in the work described in the present paper, we (a) determined the levels of 15 selected plasma metabolites and enzyme activities in free-living Osprey nestlings, (b) discerned the effects of relevant factors such as sex and age on these variables, and (c) derived relationships between nutritional parameters and simple condition indices. We also (d) examined the potential effect that habitat quality, measured in terms of feeding conditions and human disturbances, could have on the physical condition of Osprey nestlings.

\section{Materials and methods}

\section{Area of study}

We studied a breeding population of Ospreys in the state of Brandenburg (eastern Germany, $52^{\circ} 15^{\prime} \mathrm{N}, 13^{\circ} 55^{\prime} \mathrm{E}$ ). In the study area, the landscape is characterized by low plains (50 $\mathrm{m}$ a.s.1.) with a mosaic of forest plantations (Pinus sylvestris), remnants of broadleaf natural forests (Quercus robur, Fagus sylvatica, Betula sp.), agricultural lands, 
freshwater lakes, and small rivers. The climate is temperate with a continental influence. Monthly average temperatures range from -1 to $18{ }^{\circ} \mathrm{C}$ (annual mean of $8.7^{\circ} \mathrm{C}$ ), and the mean annual rainfall is $510 \mathrm{~mm}$ (Deutscher Wetterdienst).

\section{Study species}

The Osprey is a large, long-lived, diurnal, and primarily migratory bird of prey that is associated with shallow waters (fresh or marine) and feeds almost exclusively on live fish (Poole 1989; del Hoyo et al. 1994). It shows a near-cosmopolitan distribution (it is not found in Antarctica), though its breeding areas are mainly the Holartic and Australasia and it has tropical and subtropical wintering grounds (Ferguson-Lees and Christie 2001). The haliaetus subsp. occurs in Europe, mainly in the northern and eastern regions, where there is an estimated overall population of 10,000 breeding pairs (BirdLife International 2012). Following a general worldwide decline due to direct persecution, use of pesticides, and a lack of suitable trees for nesting (Saurola 1997), the Osprey population in Germany has experienced a gradual recovery since the 1970s, with increasing population density and spatial expansion (Schmidt 2001, 2010). The German Osprey population had increased to 550 nesting pairs by 2009 , with a mean productivity of 1.7 young per active nest (Schmidt 2010). This expansion has been associated with adaptation to anthropogenic environmental conditions, since $75 \%$ of the population currently nest on pylons, and the birds are occupying more open and populated areas than they were previously (Bai et al. 2009).

\section{Data collection}

During June-July 2006, we sampled 28 Osprey nestlings, 26-46 days old, from 16 nests with brood sizes varying from one to four chicks. Nestlings were therefore in the mid-to-late nestling period, since they fledge on average when 50-55 days old in migratory populations (Stinson 1977; Poole 1989). Seven nests were on active pylons, eight were on unused pylons, and one was on a hunting hut. Young were ringed with a metal ring from the Hiddensee Bird Ringing Centre on one tarsus and a color-coded ring that could be identified from distance on the other tarsus. When the hatch date was not known, age was estimated according to plumage development and the length of the flattened wing chord (Schaadt and Bird 1993) using a metal ruler to the nearest $1 \mathrm{~mm}$. We also measured body mass with 2,500 g spring scales (Pesola AG, Switzerland) to the nearest $10 \mathrm{~g}$ (the scale had $20 \mathrm{~g}$ divisions, but was read to the nearest $10 \mathrm{~g}$ when the measurement was equidistant between divisions), and the forearm length as an indicator of body size (from the front of the folded wrist to the proximal extremity of the ulna) using a digital caliper (Muytoyo Corp.) to the nearest $0.1 \mathrm{~mm}$ (Muriel et al. 2010).

Plasma parameters and sex determination

Using a hypodermic needle, $2 \mathrm{ml}$ of blood were extracted from the brachial vein of the wing and collected in lithium heparin tubes to prevent coagulation. Blood samples were drawn between $10: 00$ and $16: 00 \mathrm{~h}$ to minimize daily variations in biochemical parameters (García-Rodríguez et al. 1987a; Ferrer 1993). Measurements can be considered postprandial, since Osprey nestlings are fed actively during the early morning, with the fish supply provided by adults to the nest peaking at 05:00-09:00 h (Stinson 1978, Poole 1989), and sunrise occurred during the sampling period at around $04: 45 \mathrm{~h}$ at the study area. Tubes were kept in cooling containers $\left(+4{ }^{\circ} \mathrm{C}\right)$ to avoid protein denaturation and hemolysis. Plasma was separated by centrifugation $(4,000 \mathrm{rpm}, 10 \mathrm{~min})$ within $8 \mathrm{~h}$ of extraction and was immediately stored at $-40{ }^{\circ} \mathrm{C}$ until analysis. The following 15 determinations were made in each plasma sample (abbreviation is indicated), except for those without sufficient plasma: urea (urease method), uric acid (uricase method), triglycerides (lipase/glycerol kinase), cholesterol (cholesterol esterase), creatinine (creatinine iminohydrolase), glucose (glucose oxidase-peroxidase), creatine kinase (CK, enzymatic method), amylase (maltoheptaose reaction), alkaline phosphatase (ALP, cresolphthalein phosphate hydrolysis), gamma-glutamyltransferase (GGT, enzymatic method), alanine aminotransferase (ALT, enzymatic method), aspartate aminotransferase (AST, enzymatic method), potassium ( $\mathrm{K}$, acid-base reactions), total calcium (Ca, o-cresolphthalein complexone), and total protein (TP, hand-held refractometer from ATAGO). The analyses were carried out with a portable autoanalyzer (Reflotron II, Boehringer Mannheim Inc.) with the reagents recommended by Roche Diagnostics $\mathrm{GmbH}$, except for two parameters-GGT and $\mathrm{Ca}$ - which were determined with a multichannel portable analyzer (Screen Point, Hospitex Diagnostics s.r.1.) using the reagents recommended by the company. Analyses were performed at a temperature of $+37{ }^{\circ} \mathrm{C}$. Samples with apparent hemolysis and lipemia were removed from the subsequent analysis. Analyzers were calibrated routinely using the Clean and Check kit and procedures recommended by the manufacturer (Roche). Some urea values were below the lower limit of the measurement range for the Reflotron. Those values were determined with the Screen Point analyzer, and the predicted values for the Reflotron were then calculated using a linear correlation derived from pairs of values obtained for the same samples using both the Reflotron and the Screen Point analyzer $\left(N=10 ; \quad r^{2}=0.9874, \quad P<0.0001\right)$. 
Biochemical tests were performed at the Laboratory of the Botanical Zoo of Jerez de la Frontera (Spain).

Around $50 \mu \mathrm{l}$ of blood were also kept in Eppendorf tubes with absolute ethanol to allow the sex of each individual to be determined, following Griffiths et al. (1998). We used the primers P8 (5'-CTCCCAAGGATGAGRA AYTG- $\left.3^{\prime}\right)$ and P2 (5'-TCTGCATCGCTAAATCCTTT- $\left.3^{\prime}\right)$ to amplify sequences from the CHDI-Z gene, which is unique to females, and the $C H D 1-W$ gene, which occurs in both males and females. Analyses were carried out at the Laboratory of Molecular Ecology at Doñana Biological Station (CSIC, Spain).

Index of body condition (IBC)

A simple but widely applied predictor of animal body condition is body mass corrected according to a measure of size (Green 2001). We used three different approaches to obtain IBCs for Osprey nestlings: ordinary least squares regression (OLS), the reduced major axis procedure (RMA), and the scaled mass index (SMI), following Green (2001) and Peig and Green (2009, 2010). OLS and RMA are based on the residuals of a regression between the natural logarithm of body mass and the natural logarithm of a morphological measurement of structural size, while SMI is calculated by rescaling body mass in relation to relative size and a derived scaling exponent (for more details, see Peig and Green 2009). We used length of forearm as an accurate indicator of body structural size (Muriel et al. 2010).

\section{Habitat quality}

We quantified habitat quality for each of the 16 sampled nests, measuring characteristics associated with trophic conditions and human disturbance. Variables related to foraging conditions were selected based on the results of a study on the foraging behavior of breeding males in a similar area of northern Brandenburg State (Schmidt 1999). Mean distance to visited lakes from nest sites was $2.3 \mathrm{~km}$, with a maximum distance of $7.3 \mathrm{~km}$, and males used only the three nearest lakes in $70 \%$ of their foraging flights. Therefore, we considered four variables: minimum distance to the nearest water body (Dist_Lake), average distance to the three nearest lakes (Dist_Lake3), and surface area of water bodies within a radius of $2.3 \mathrm{~km}$ (Area_2) and $7.3 \mathrm{~km}$ (Area_7) from the nest. Ospreys tend to use shorelines for fishing and to avoid the deeper central parts of large lakes (Saurola and Koivu 1987; Poole 1989). Hence, following the results attained by Löhmus (2001), we only considered an inner band $300 \mathrm{~m}$ wide from the shoreline for surface estimation purposes. Despite the fact that Ospreys are relatively tolerant of human presence (Poole 1989), we considered three more predictors to account for potential human disturbances: the distances to the nearest unpaved road (Dist_UnPRoad), paved road (Dist_PRoad), and settlement (Dist_Settl). Land features were estimated using Geographic Information System software (ArcGis 9.2 and ArcView 3.2, ESRI Inc.) and Google Earth 5.0 (Google Inc.). Digitized data on water body cover were provided by the Office of Environment, Health and Consumer Protection of Brandenburg State.

Because of partial covariation among habitat quality predictors, the original number of variables (seven) was reduced in a principal components analysis (Jambu 1991). The first and second principal components (PC1, PC2) explained 49.2 and $22.5 \%$ of the original variance, respectively, and placed each nest in a double environmental gradient. PC1 ranged from -2.817 to 4.810 and was related to feeding conditions of the habitat, since positive values indicated increased proximity to lakes and high water body surface area around the nest (Table 1). Likewise, PC2 ranged from -1.742 to 3.175 and was associated with potential human disturbance, with positive values denoting longer distances from human infrastructures (Table 1). Therefore, positive values of both components were related to potentially higher habitat quality.

\section{Data analysis}

We used generalized linear mixed models (GLMMs) with the GLIMMIX macro of the SAS 9.2 software package to examine differences between sexes in terms of plasma metabolite levels, enzymatic activity, and body measurements. We ran a simple model for each of the 15 parameters, where the parameter was the response variable, the factor "sex" was the fixed factor, and "age" was the covariate, in order to account for possible developmental

Table 1 Contribution of each original habitat feature to the first two principal components obtained in the PCA that was performed in order to combine and reduce the number (initially seven) of descriptive variables

\begin{tabular}{lrr}
\hline Code & Loading PC1 & Loading PC2 \\
\hline Dist_Lake & $\mathbf{- 0 . 8 5 6 8 1 8}$ & -0.006017 \\
Dist_Lake3 & $\mathbf{- 0 . 8 8 1 0 2 0}$ & -0.066659 \\
Area_2 & $\mathbf{0 . 7 7 1 4 4 1}$ & 0.181342 \\
Area7c & 0.631888 & 0.323724 \\
Dist_UnPRoad & $\mathbf{0 . 7 9 9 1 7 2}$ & 0.240323 \\
Dist_PRoad & -0.279150 & $\mathbf{0 . 8 4 3 9 7 5}$ \\
Dist_Settl & -0.473563 & $\mathbf{0 . 7 7 0 3 2 8}$ \\
\hline
\end{tabular}

Absolute loading values $>0.7$ are marked in bold 
differences. The interaction between both explanatory variables ("sex $\times$ age") was also included in the initial model. Given that siblings from the same nest share the same genetic background, parental care, and environmental conditions, their plasma values are not independent, so we also considered "nest" as a random effect in the models to avoid pseudoreplication. We fitted the GLMMs with a normal distribution and an identity link. We checked each model for normality of residuals. When they were nonnormal, the response variables were log-transformed to attain normality. Hypotheses were tested using $F$ statistics for fixed factors and $Z$ statistics for random effects (Littell et al. 2006). When nonsignificant $(P<0.1)$, the interaction term "sex $\times$ age" was removed from the model and only main effects were examined.

We assessed potential relationships between the three IBCs derived by rescaling body mass with respect to forearm length as body size measurements (OLS, RMA, SMI) and the levels of six plasma biochemical parameters traditionally associated with energy reserves (urea, uric acid, triglycerides, cholesterol, glucose, and total protein). Simple linear regressions were performed for each of those plasma parameters (as the response variable) and each of the IBCs (as the predictor).

Urea levels were used to check for possible relationships between the nestling physical condition and habitat quality, as measured by the two predictors derived from PCA. Urea concentration has frequently been used as an accurate indicator of nutritional state in bird species with poor fat reserves, such as birds of prey (García-Rodríguez et al. 1987a). During starvation periods, tissue proteins are actively mobilized as an energy source, leading to an increase in the nitrogenous excretion components in blood derived from protein catabolism. Hence, plasma urea values tend to increase when the bird is undernourished and recover after feeding (García-Rodríguez et al. 1987a; Alonso-Álvarez and Ferrer 2001). We ran a GLMM with "urea" as the response variable, using a normal distribution of residuals and an identity link. Normality of errors was tested. The explanatory variables were "PC1" and "PC2" as predictors of habitat feeding conditions and potential human disturbances, respectively, as well as "sex," "brood size," "hatch date" (with "1" being the earliest hatch date recorded), and "age." Given that there was only one brood and only one nest with four chicks, we re-categorized "brood size" into two levels: broods with 1-2 chicks and those with three or more nestlings. All first-order interactions of fixed factors were also included in the model. In addition, "nest" was considered a random factor to account for nonindependence among siblings. We fitted the effects of the explanatory variables to the observed data via backward selection, removing nonsignificant terms $(P<0.1)$ from the initial full model until only significant terms remained. We checked the significance of interaction terms first and then the main effect terms. When an interaction was significant, we left both main effects in the final model, even if they were not significant.

Finally, we also checked for possible effects of both environmental descriptors on the productivity of the sampled Osprey population. Two GLMMs were run using "clutch size" and "brood size" as response variables. Both variables were re-categorized into two levels as previously described for "brood size" (1-2 and 3-4 eggs/chicks, respectively), and thus a binomial distribution with a logit link was used (Littell et al. 2006). "PC1," "PC2," and their interaction " $\mathrm{PC} 1 \times \mathrm{PC} 2$ " were introduced as explanatory variables in the model. When it was not significant, the interaction was removed in order to test only for main effects of predictors.

All data are expressed as the mean \pm standard deviation (SD). Minimum-maximum values (range) and reference ranges, obtained by determining $95 \%$ confidence intervals $(95 \% \mathrm{CI})$, are also provided. Statistics were analyzed using the SAS 9.2 (SAS Institute Inc., Cary, NC, USA) and STATISTICA 8.0 (Statsoft 2002, Tulsa, OK, USA) software packages. Differences were considered significant at $P \leq 0.05$, unless noted otherwise.

\section{Results}

\section{Effects of sex and age}

Normal reference plasma biochemistry values for freeliving male and female Osprey nestlings are shown in Table 2. Sexual differences were found for two of the fifteen plasma parameters measured after controlling for territory (nest) and age. Males presented lower urea and higher glucose levels than females. In addition, seven parameters showed significant covariation with age. Whereas urea, uric acid, triglycerides, glucose, AST, and calcium values increased with age, potassium showed a decreasing trend with age.

IBCs and plasma parameters

Body mass was positively and significantly correlated with forearm length of Osprey nestlings $\left(r^{2}=0.586\right.$, $P<0.001)$. However, neither the OLS, RMA, nor SMI indices were significantly correlated with the levels of urea, uric acid, triglyceride, cholesterol, glucose, or total protein in plasma $(P<0.05)$. As significant sex differences were found for the urea and glucose levels, the factor "sex" was included in those models, but no significant relationships were found. 


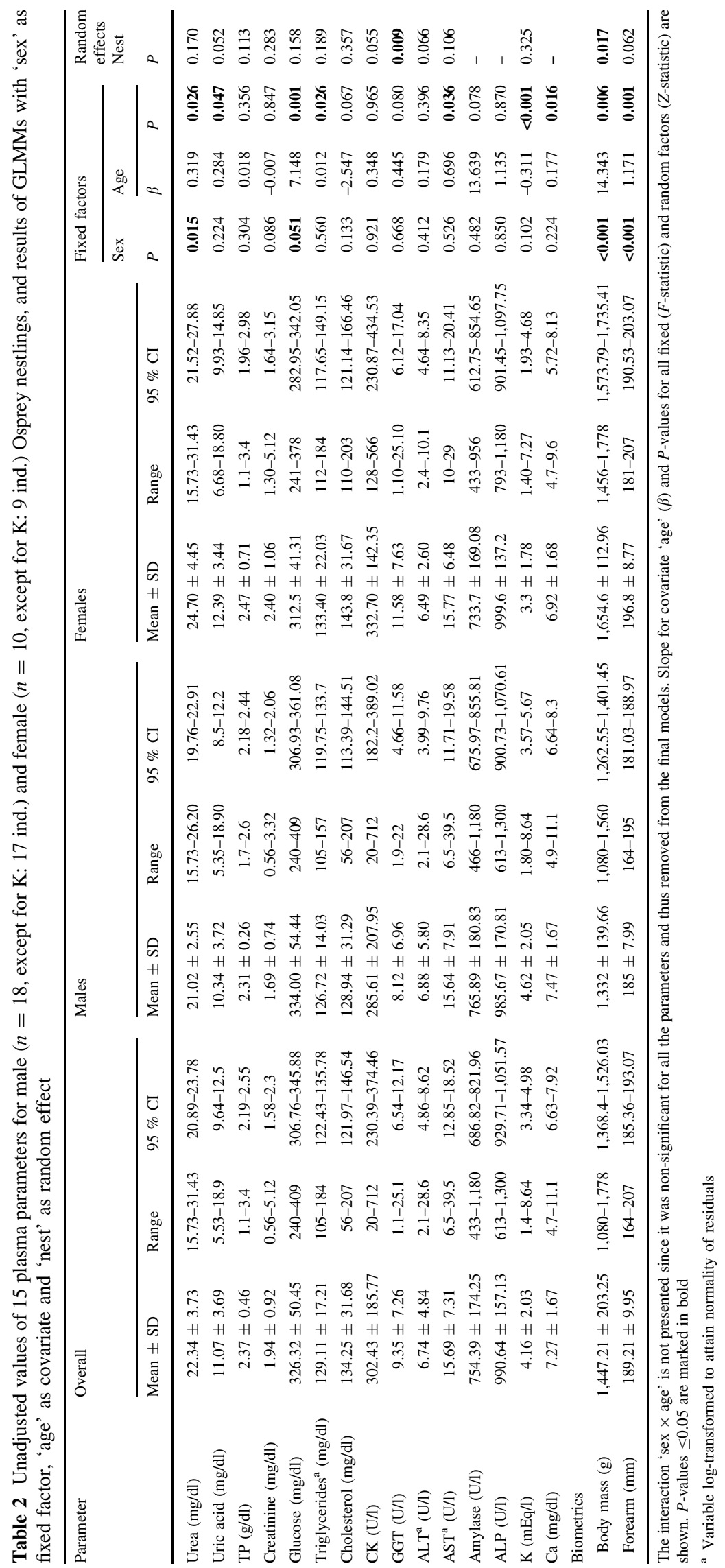


Habitat quality, nestling physical condition, and productivity

Nutritional condition, as measured via urea plasma concentration, was affected by habitat feeding conditions (PC1) (Table 3). However, this relationship was dependent on brood size, as only nestlings from large broods of three or more chicks showed lower urea values with increasing PC1 scores, while the urea levels of chicks from small broods did not vary significantly with PC1 (Fig. 1). In other words, the nutritional condition of nestlings from large broods improved as habitat trophic quality improved due to increased proximity to lakes and increased water body area. On the other hand, nestling nutritional condition was not related to human disturbances (PC2). Significant sex differences for urea remained after the samples had been corrected for possible effects of habitat and brood size, whilst age was not found to be relevant when accounting for the other explanatory variables.

Habitat feeding conditions and potential human disturbance did not affect the productivities of sampled nests, as measured via clutch size (PC1: $F_{1,13}=1.23, P=0.287$; PC2: $\left.F_{1,13}=0.46, P=0.508\right)$ and brood size $(\mathrm{PC} 1$ : $F_{1,13}=0.12, P=0.730$; PC2: $\left.F_{1,13}=2.60, P=0.131\right)$.

\section{Discussion}

\section{Plasma reference values}

In this work, we provide the normal ranges for 15 plasma biochemical parameters in free-living Osprey nestlings (Table 2), and this is the first time that these ranges have been reported in the literature. The ranges of most plasma components of Osprey neslings overlap with those reported for nestlings of other falconiform species, but there are

Table 3 GLMM explaining variation in urea level as an indicator of body condition in Osprey nestlings $(n=28)$ in relation to habitat characteristics derived from PCA

\begin{tabular}{llrll}
\hline Explanatory variables & $d f$ & $F$ & $Z$ & $P$ \\
\hline Fixed effects & & & & \\
Brood size & 1.11 & 6.43 & & 0.028 \\
Sex & 1.11 & 13.87 & & 0.003 \\
PC1 & 1.11 & 13.04 & & 0.004 \\
Brood size $\times$ PC1 & 1.11 & 12.75 & & 0.004 \\
Random effect & & & & \\
Nest & & & 1.02 & 0.155 \\
\hline
\end{tabular}

Model selection was based on backward selection of significant terms from the full model, including "hatch date," "brood size," "sex," "age," "PC1," "PC2" and first interaction terms as explanatory variables. "Nest" was also considered as a random factor

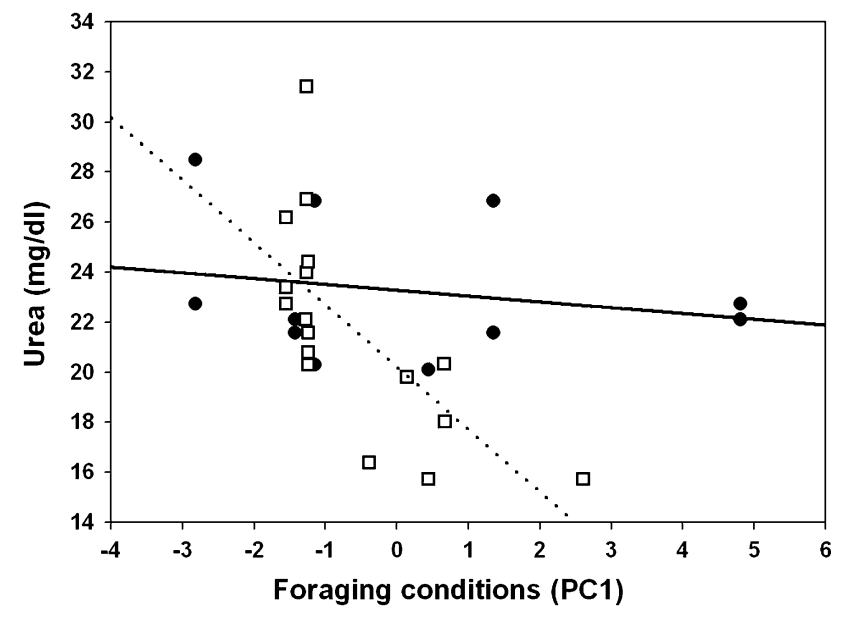

Fig. 1 Relationship between foraging conditions around the nest (PC1) and urea level in Osprey nestlings for different brood size categories (filled circles small broods of 1-2 chicks, squares large broods of 3-4 chicks). More positive values of PC1 denote larger lake surface areas and shorter distances to water bodies, and thus better feeding conditions. Lines represent the best linear fits for the two brood size categories (solid line small broods, dotted line large broods)

several notable exceptions (the "Appendix" lists biochemical values for the following species: Aegypius monachus, Villegas et al. 2002; Aquila adalberti, Ferrer and Dobado-Berrios 1998; Aquila chrysaetos, Balasch et al. 1976; Aquila fasciata, Balbontín and Ferrer 2002; Aquila pennata, Casado et al. 2002; Buteo swainsoni, Sarasola et al. 2004; Gymnogyps californianus, Dujowich et al. 2005; Haliaeetus leucocephalus, Mealey et al. 2004; Neophron percnopterus, Dobado-Berrios et al. 1998; Pseudogyps africanus, Van Wyk et al. 1998). The Osprey nestlings in this study generally showed noticeably higher values of urea, uric acid, glucose, creatinine, and to a lesser extent triglyceride, as well as lower values of total protein and cholesterol, than those other species. Lower levels of $\mathrm{CK}$ and hepatic transaminase enzymes (ALT, AST, GGT) were also detected in Osprey nestlings. Depending on the species and reference work considered, the differences varied from slight to strong. For instance, mean concentrations of hepatic enzymes and CK in Ospreys were up to 10-20 times lower than they are in other raptors (i.e., A. adalberti, A. fasciata, A. monachus, or H. leucocephalus), and creatinine values were between five and eight times higher in Osprey than in most other raptors or in other nonraptorial bird species which feed on fish (e.g., Pelecanus crispus, Polo 1995; P. onocrotalus, Shmueli et al. 2000). High levels of AST and (particularly) CK in healthy birds have been related to muscle cell damage (Hotchleithner 1994), physical activity (Fourie and Hattingh 1980), capture and manipulation stress (Chalmers and Barret 1982), and body mass (Polo 1995). Hence, lower 
levels of these enzymes in nestling Ospreys may be due to a combination of smaller body size and lower muscular stress at nestling stage in comparison to those cited species, all of which are notably larger. Other parameters such as $\mathrm{Ca}$ did not exhibit unusual trends compared with their values in the other species, except for $A$. adalberti and $N$. percnopterus, which showed higher calcium values. The consistent interspecific variations found may be attributed to evolutionary differences in basal physiology, since the Osprey constitutes a monospecific family that is clearly separated from other taxa within Falconiformes based on molecular phylogeny (Wink and Sauer-Gürth 2000; Lener and Mindell 2005). Additionally, the specialized diet of the Osprey, based exclusively on fish, might influence its normal plasma chemistry pattern. In any case, care must be taken when interpreting interspecific variations in biochemical values, even within the same group. Factors such as captivity, diet, physical activity, circadian cycles, and analytic methods may result in greater differences between species than expected (Ferrer 1993).

\section{Effect of sex and age}

Although birds are considered uricotelic, the mean urea concentration in Osprey nestlings was still double the mean concentration of uric acid. This higher contribution of urea to nitrogenous waste is a phenomenon that has already been observed to occur in other raptors (e.g., Ferrer and Dobado-Berrios 1998; Casado et al. 2002; Balbontín and Ferrer 2002) and piscivorous species like storks, pelicans, and herons, as a result of a diet rich in protein (Polo 1995). Female nestlings showed higher urea levels than males. Although the reason for this difference between the sexes is not completely clear, higher urea levels could be related to higher food demand in female nestlings as a result of higher net growth rates. In bird species with a noticeable sexual size dimorphism, like the Osprey (Schaadt and Bird 1993; Muriel et al. 2010), growth patterns may differ between sexes throughout the nestling period. Female Ospreys show higher overall growth rates than males, especially during the late nestling period from 20 to 25 days onwards, when males slow down their growth while females keep on growing until they reach their asymptotic mass (Poole 1989; Schaadt and Bird 1993). Hence, the higher food demand of females during the second half of the nestling period could explain the higher values of urea.

The trend for both urea and uric acid values to rise with nestling age may be associated with the progressive maturation of nestling renal function, which increases the clearance of nitrogen waste products (Costa et al. 1993; Dobado-Berrios et al. 1998). These increasing levels may also reflect increased protein turnover as a consequence of the rapid growth process (Dobado-Berrios et al. 1998). However, other factors such as the amount of protein ingested with the feed, individual nutritional status, and metabolic differences may influence plasma urea and uric acid levels. Future studies on age-related variations in protein catabolism and nitrogen excretion would be desirable in order to disentangle the role of parameters like urea level and uric acid level during early development in birds.

Both triglyceride concentration and cholesterol concentration are related to fat reserves, and are therefore relatively low in bird species with diets rich in protein, such as birds of prey (Griminger 1976; Polo 1995). Osprey nestlings showed rising concentrations of triglyceride with age, probably as a result of general increases in energy reserves and weight as well as a more active endogenous lipid metabolism associated with increasing physical activity during the growth stage prior to fledging (Van Wyk et al. 1998). However, we did not detect a positive correlation between cholesterol and triglycerides. A priori, a positive correlation between triglyceride concentration and cholesterol concentration would be expected, since both reflect lipid reserves. Nevertheless, Polo (1995) did not observe this positive relationship in Falconiformes, nor in other bird species.

We observed differences in plasma glucose levels between the sexes of nestling Ospreys, with males showing higher values than females. As previously noted for urea, higher overall growth rates in females during the late nestling period could lead to lower glucose levels, given that they present greater energy demands during the late growth stage, and might channel glucose reserves into tissue formation (Balbontín and Ferrer 2002). However, glucose plasma levels have shown to be highly variable because glucose is used as a rapid and immediate energy source, and depends on metabolic rate, body size, and food intake (Umminger 1977; García-Rodríguez et al. 1987b). In addition, the increase in glucose level with age observed for Osprey nestlings might be a consequence of increases in metabolic rate and weight, as already noted for several species (e.g., González and Hiraldo 1991; Ferrer and Dobado-Berrios 1998; Villegas et al. 2002; Juráni et al. 2004). In fact, as already explained for triglyceride and protein metabolism, higher glucose mobilization would be expected at the end of the nestling period, when physical activity is higher as nestlings prepare for their first flight.

Variations in transaminase enzymes like AST are difficult to interpret, since their distributions in different tissues and organs can vary among species, and may be affected by factors as diverse as muscular and soft-tissue injury, physical activity, stress, nutritional status, hydration, hemolysis, liver disease, etc. (Bell and Freeman 1971; Polo 1995). Since the Osprey nestlings analyzed did not show any apparent clinical signs of disease, the increase in AST 
with age could be related to higher physical activity and flight exercises prior to fledging, which may lead to muscular stress and result in increasing AST values.

Calcium concentrations in plasma have been related to chondrogenesis, osteoblastic activity, and bone mineralization during the growth period in birds (Viñuela et al. 1991; Tilgar et al. 2004). Thus, the increasing concentrations we observed in Osprey nestlings are expected during the growth stage, with maximum values occurring at the end of structural development before fledging. However, we did not find a parallel increase in the enzyme ALP, which is associated with the elongation and ossification of skeletal structures (Viñuela et al. 1991; Tilgar et al. 2008). A similar absence of covariation in ALP with age has also been observed in other species (Costa et al. 1993; Dobado-Berrios and Ferrer 1997; Niezgoda et al. 1984). It is possible that the peak of ALP had already been attained, resulting in a plateau within the sampled age range, whereas the increase in calcium was slightly delayed to complete bone ossification. In this context, Viñuela et al. (1991) found that calcium levels reached their maximum after ALP in Red Kites (Milvus milvus) and Black Kites (M. migrans).

Muscular activity is known to increase intracellular potassium and thus to reduce its plasma concentration (Wolf et al. 1985). Hence, the decreasing potassium values observed in the Osprey nestlings with age might be related to increasing physical activity prior to fledging, as already observed in other raptors (Dujowich et al. 2005).

\section{IBCs and plasma parameters}

One of the objectives of our study was to test the relationships of certain plasma parameters employed as nutritional indicators with the estimated IBCs. High values of urea and uric acid have proven to be good indicators of undernourishment (Ferrer et al. 1987; Polo 1995), while total protein concentrations tend to decrease under conditions of malnutrition (Smith and Bush 1978). Triglyceride and cholesterol values are related to lipid ingestion as well as endogenous synthesis (Ferrer et al. 1987), and glucose values may decrease with prolonged food deprivation (García-Rodríguez et al. 1987b). However, none of these parameters showed significant correlations with the three estimated body indices OLS, RMA, and SMI.

The general absence of a relationship between any of the selected plasma metabolites and IBCs may indicate high homogeneity in the nutritional conditions of the birds studied here, particularly given the apparent good feeding conditions of the study area. It is likely that detectable nutritional differences only arise following a minimum starvation period or when a generalized disease strikes that affects the physical state. Specific food deprivation experiments performed under controlled conditions with larger sample sizes might help us to understand the effects of nutritional stress on plasma biochemistry and IBCs in Ospreys. In any case, reported correlations between IBCs and biochemical parameters have usually been poor or irrelevant (e.g., De le Court et al. 1995; Villegas et al. 2002; Hanauska-Brown et al. 2003), since relationships between body mass and structural measurements can be masked by individual morphological variability in the absence of a significant gradient in the nutritional condition of the sampled individuals.

Habitat quality, nestling physical condition, and productivity

Our results showed that Ospreys do not tend to adjust their initial reproductive investment in relation to the foraging conditions of the surrounding habitat, since clutch size and the number of nestlings were not affected by predictors of habitat quality. Therefore, initial investment is most probably related to other factors, such as parental quality and (mainly) female physical condition before the eggs are laid, as has been shown for other species (e.g., Ferrer 1994; Vergara et al. 2010). In fact, in migratory bird species, reproductive effort may rely to some extent on postmigratory body condition, and thus on the endogenous resources stored prior to arrival (Klaassen et al. 2006). Our results are consistent with previous studies on migratory Osprey populations, which also found no correlation between clutch size or initial brood size and foraging conditions, nor between feeding rate and brood size during the nestling period (Stinson 1978; Jamieson et al. 1983; Eriksson 1986). Therefore, reduced provision of fish and lower fledgling weight would be expected in larger broods (Stinson 1977). In contrast, other studies have detected positive correlations between productivity and foraging conditions (Löhmus 2001). Interestingly, we found that nestling nutritional condition (measured via the urea level) was positively related to habitat foraging predictors, but only in large broods, not in small ones. In lower-quality habitats, nestling nutritional condition did not vary significantly with brood size, but nestlings in large broods showed lower urea values and thus better nourishment than those from small broods when feeding conditions improved. Thus, a posthatch productivity adjustment seems to occur-at least in terms of offspring quality-in relation to habitat trophic characteristics, and is modulated by parental quality and initial investment. When food availability is high, parents in better physical condition and larger broods are able to rear more nestlings even with a better physical condition than lower-quality parents with fewer chicks. In this sense, more direct measurements of habitat productivity, like fish availability or trophic indices, would be desirable in order to obtain a more comprehensive understanding of these 
relationships between habitat foraging quality and nestling nutritional condition.

Nestling body condition and productivity were not influenced by the proximity of human infrastructure. Although some previous works have found a negative relation between proximity of human activities and productivity (Van Daele and Van Daele 1982), the Osprey is considered a relatively tolerant species that has rapidly adapted to human presence. In fact, the population increase and expansion of Osprey in areas of central Europe, such as Germany, has been related to the use of pylons (which provide readily available and stable nesting structures) and the occupation of agricultural areas with more productive lakes (Bai et al. 2009), as well as the early banning of DDT and increasing ecological awareness (Schmidt 2001). Therefore, Ospreys may habituate to low-to-moderate amounts of human disturbance without suffering any negative effects on their breeding success.

\section{Conclusions}

In the present study, we obtained reference plasma values of free-living nestling Ospreys for the first time. The highly specialized fish diet and possible basal physiological variations of this particular falconiform are likely to be responsible for the observed significant differences of these values from those published for other raptor nestlings. Variations with age, which were seen for several parameters, seem to be related to increasing metabolic rates and body mass during the growth stage before fledging, which would lead to higher mobilization of metabolites linked with energy reserves and physical activity. Sexual differences in urea and glucose values would arise as a consequence of differential growth rates between genders, which are characteristic of species with sexual size dimorphism such as the Osprey. We have also shown that traditional IBCs do not have any significant correlations with selected plasma parameters associated with nutritional condition. This absence of a clear pattern could be due to high homogeneity in the (generally good) physiological conditions of the birds sampled in this work, but could also be due to the poor results that body mass residuals on size can provide, as noted in previous studies. Finally, Ospreys seem to indirectly adjust parental investment during the nestling stage. Foraging quality of the habitat may affect nestling physical condition (gauged using urea level in plasma), at least in large broods.

Acknowledgments We are grateful to the Kreig and Bennewitz families for their hospitality and help in Germany, to Mr. Weiss and Mr. Heuer for their collaboration in the field, as well as to J. Giralt and M. Ríos, who collaborated as volunteers during the field work. We thank the Director and staff of the Botanical Zoo of Jerez, who allowed us to use the laboratory, the Office of Environment, Health and Consumer Protection of Brandenburg State for providing GIS data, and the German power company for facilitating the sampling of nests on certain pylons. We are also grateful to T. Mackrill and two anonymous referees who helped to improve the manuscript. R. Muriel was an FPU fellow (Ministry of Education, Government of Spain), and his work was partially funded by a temporary stay grant from the FPU program. The work of D. Schmidt was partly funded by the Deutsche Ornithologen-Gesellschaft DO-G. This study complies with the current laws of Germany and Spain.

\section{Appendix}

See Table 4. 







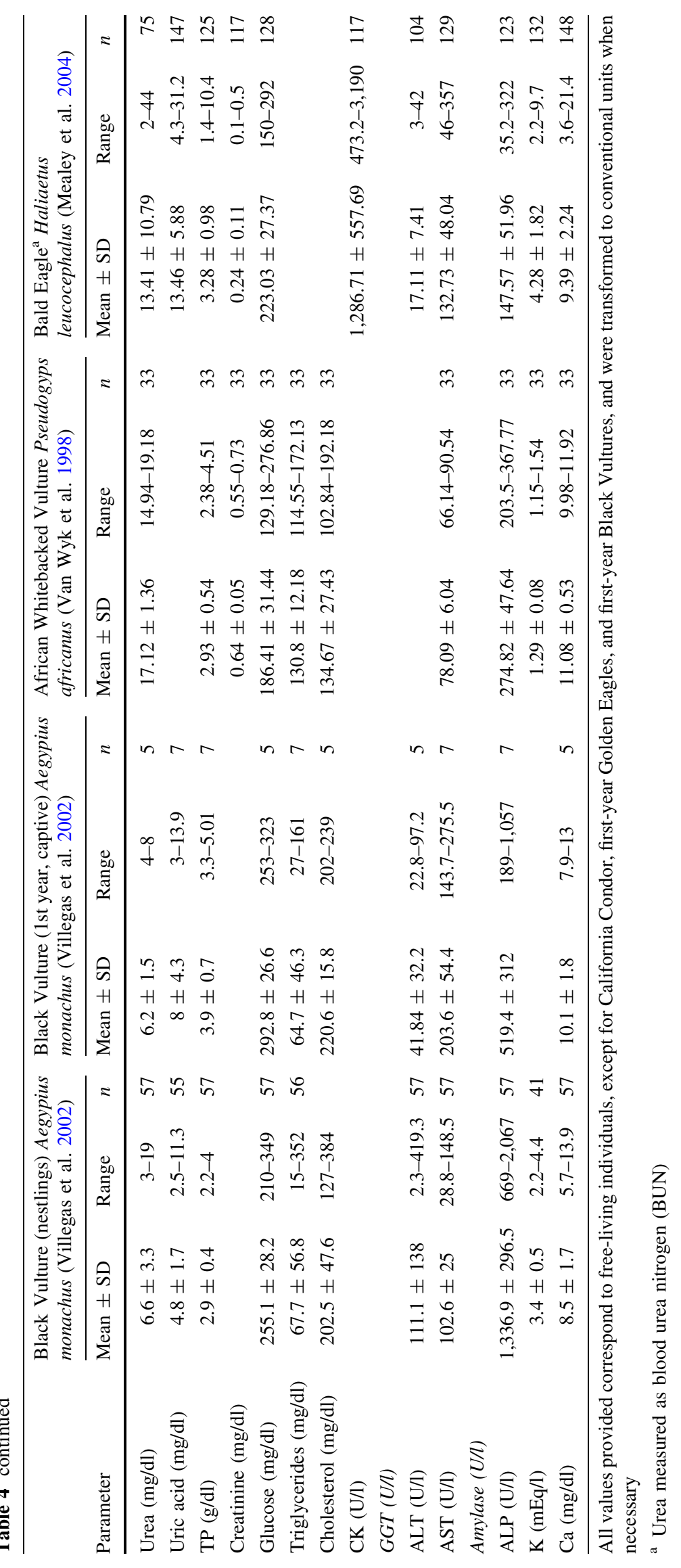




\section{References}

Alonso-Álvarez C (2005) Age-dependent changes in plasma biochemistry of yellow-legged gulls (Larus cachinnans). Comp Biochem Physiol A 140:512-518

Alonso-Álvarez C, Ferrer M (2001) A biochemical study of fasting, subfeeding, and recovery processes in Yellow-Legged Gulls. Physiol Biochem Zool 74:703-713

Bai M-L, Schmidt D, Gottschalk E, Mühlenberg M (2009) Distribution pattern of an expanding Osprey (Pandion haliaetus) population in a changing environment. J Ornithol 150:255-263

Balasch J, Musquera S, Palacios L, Jiménez M, Palomeque J (1976) Comparative hematology of some falconiforms. Condor 78:258-273

Balbontín J, Ferrer M (2002) Plasma chemistry reference values in free-living Bonelli's eagle (Hieraaetus fasciatus) nestlings. J Raptor Res 36:231-235

Bell DJ, Freeman BM (1971) Physiology and biochemistry of the domestic fowl. Academic, London

BirdLife International (2012) Pandion haliaetus. In: IUCN (eds) IUCN Red List of threatened species, version 2012.1. http://www.iucnredlist.org/

Casado E, Balbontín J, Ferrer M (2002) Plasma chemistry in Booted Eagle (Hieraaetus pennatus) during breeding season. Comp Biochem Physiol A 131:233-241

Chalmers GA, Barret MW (1982) Capture myopathy. In: Hoff GL, Davis JW (eds) Noninfectious diseases of wildlife. Iowa State University Press, Ames, pp 84-94

Costa ND, MacDonald DE, Swan RA (1993) Age-related changes in plasma biochemical values of farmed Emus (Dromaius novaehollandiae). Aust Vet J 70:341-344

De le Court C, Aguilera E, Recio F (1995) Plasma chemistry values of free-living White Spoonbills (Platalea leucorodia). Comp Biochem Physiol A 112:137-141

Del Hoyo J, Elliot A, Sargatal J (1994) Handbook of the birds of the world, vol 2: New World vultures to guineafowl. Lynx Edicions, Barcelona

Dobado-Berrios PM, Ferrer M (1997) Age-related changes of plasma alkaline phosphatase and inorganic phosphorus, and late ossification of the cranial roof in the Spanish imperial eagle (Aquila adalberti C. L. Brehm, 1861). Physiol Biol 70:421-427

Dobado-Berrios PM, Tella JL, Ceballos O, Donázar JA (1998) Effects of age and captivity on plasma chemistry values of the Egyptian vulture. Condor 100:719-725

Dujowich M, Mazet JK, Zuba JR (2005) Hematologic and biochemical reference ranges for captive California condors (Gymnogyps californianus). J Zoo Wildl Med 36:590-597

Eriksson MOG (1986) Fish delivery, production of young, and nest density of Osprey (Pandion haliaetus) in southwest Sweden. Can J Zool 64:1961-1965

Ferguson-Lees J, Christie DA (2001) Raptors of the world. Houghton Mifflin Company, Boston

Ferrer M (1992a) Regulation of the period of postfledgling dependence in the Spanish Imperial eagle Aquila adalberti. Ibis 134:128-133

Ferrer M (1992b) Natal dispersal in relation to nutritional condition in Spanish imperial eagles. Ornis Scand 23:104-107

Ferrer M (1993) Blood chemistry studies in birds: some applications to ecological problems. Comp Biochem Physiol 1:1031-1044

Ferrer M (1994) Nutritional condition of Spanish Imperial Eagle nestlings Aquila adalberti. Bird Study 41:120-123

Ferrer M, Dobado-Berrios P (1998) Factors affecting plasma chemistry values of the Spanish Imperial Eagle, Aquila adalberti. Comp Biochem Physiol A 120:209-217

Ferrer M, García-Rodríguez T, Carrillo JC, Castroviejo J (1987) Hematocrit and blood chemistry values in captive raptors (Gyps fulvus, Buteo buteo, Milvus migrans, Aquila heliaca). Comp Biochem Physiol A 87:1123-1127

Fourie F, Hattingh J (1980) Variability in bird haematology. Comp Biochem Physiol A 65:147-150

García-Rodríguez T, Ferrer M, Carrillo JC, Castroviejo J (1987a) Circadian rhythms of determined blood chemistry values in buzzards and eagle-owls. Comp Biochem Physiol A 88:663-669

García-Rodríguez T, Ferrer M, Carrillo JC, Castroviejo J (1987b) Metabolic responses of Buteo buteo to long-term fasting and refeeding. Comp Biochem Physiol A 87:381-386

González JL, Hiraldo F (1991) Some hematological data from marsh harriers (Circus aeroginosus) in central Spain. Comp Biochem Physiol A 100:735-737

Green AJ (2001) Mass/length residuals: measures of body condition or generators of spurious results? Ecology 85:1473-1483

Griffiths R, Double MC, Orr K, Dawson RJG (1998) A DNA test to sex most birds. Mol Ecol 7:1071-1075

Griminger P (1976) Protein metabolism. In: Sturkie PD (ed) Avian physiology. Springer, New York, pp 233-251

Grove RA, Henny CJ, Kaiser JL (2009) Osprey: worldwide sentinel species for assessing and monitoring environmental contamination in rivers, lakes, reservoirs, and estuaries. J Toxicol Env Health B 12:25-44

Hanauska-Brown LA, Dufty AM, Roloff GJ (2003) Blood chemistry, cytology, and body condition in adult Northern Goshawks (Accipiter gentilis). J Raptor Res 37:299-306

Harmata PJ, Restani M, Harmata AR (2007) Settlement patterns, foraging behavior, and reproductive success of ospreys along a heterogeneous riverine corridor. Can J Zool 85:56-62

Hotchleithner M (1994) Biochemistries. In: Ritchie BW, Harrison GJ, Harrison LR (eds) Avian medicine: principles and application. Wingers, Lake Worth, pp 223-245

Jambu M (1991) Exploratory and multivariate data analysis. Academic, New York

Jamieson IG, Seymour NR, Bancroft RP, Sullivan R (1983) Sibling aggression in nestling ospreys in Nova Scotia. Can J Zool 61: 466-469

Jerzak L, Sparks TH, Kasprzak M, Bochenski M, Kaminski P, Wisniewska E, Mroczkowski S, Tryjanowski P (2010) Blood chemistry in white stork Ciconia ciconia chicks varies by sex and age. Comp Biochem Physiol B 156:144-147

Johnson DH, Krapu GL, Reinecke KJ, Jorde DG (1985) An evaluation of condition indices for birds. J Wildlife Manage 49:569-575

Juráni M, Výboh P, Zeman M, Lamošová D, Košt'ál L, Blažíček P (2004) Post-hatching dynamics of plasma biochemistry in free living European starlings (Sturnus vulgaris). Comp Biochem Physiol A 138:89-95

Kjellén N, Hake M, Alerstam T (2001) Timing and speed of migration in male, female and juvenile Ospreys Pandion haliaetus between Sweden and Africa as revealed by field observations, radar and satellite tracking. J Avian Biol 32:57-67

Klaassen M, Abraham KF, Jefferies RL, Vrtiska M (2006) Factors affecting the site of investment, and the reliance on saving for arctic breeders: the capital-income dichotomy revisited. Ardea 94:371-383

Lener HRL, Mindell DP (2005) Phylogeny of eagles, Old World vultures, and other Accipitridae based on nuclear and mitochondrial DNA. Mol Phylogenet Evol 37:327-346

Littell RC, Milliken GA, Stroup WW, Wolfinger RD, Schabenberger O (2006) SAS for mixed models. SAS Institute Inc., Cary

Löhmus A (2001) Habitat selection in a recovering Osprey Pandion haliaetus population. Ibis 143:651-657

Mealey B, Parks GM, Pages CM, Millsap BA, Bass OL, Bossart GD (2004) Serum chemistry values for nestling bald eagles 
(Haliaeetus leucocephalus) in Florida Bay, Everglades National Park. J Raptor Res 38:96-100

Muriel R, Casado E, Schmidt D, Calabuig CP, Ferrer M (2010) Morphometric sex determination of young Ospreys Pandion haliaetus using discriminant analysis. Bird Study 57:336-343

Niezgoda J, Pierzchala K, Lang D (1984) Levels of calcium and phosphatase in blood plasma of Japanese Quails. In: Janowski TM, Zakl NI (eds) Wybrane. Zagadnienia Fizjol. Endokrynol. Zwierzat Uzytkowych. Ossolinskich, Wroclaw, Poland, pp 103-114

Peig J, Green AJ (2009) New perspectives for estimating body condition from mass/length data: the scaled mass index as an alternative method. Oikos 118:1883-1891

Peig J, Green AJ (2010) The paradigm of body condition: a critical reappraisal of current methods based on mass and length. Funct Ecol 24:1323-1332

Polo FJ (1995) Estudio bioquímico y enzimático del plasma de aves en cautividad (Ph.D. dissertation). Universitat de Barcelona, Barcelona

Poole AF (1989) Ospreys. A natural and unnatural history. Cambridge University Press, Cambridge

Sarasola JH, Negro JJ, Travaini A (2004) Nutritional condition and serum biochemistry for free-living Swainson's Hawks wintering in central Argentina. Comp Biochem Physiol A 137:697-701

Saurola PL (1997) The osprey (Pandion haliaetus) and modern forestry: a review of population trends and their causes in Europe. J Raptor Res 31:129-137

Saurola PL, Koivu J (1987) Saaksi (The Osprey)-Kanta-Hameen Lintumiehet r.y., Forssa

Schaadt CP, Bird DM (1993) Sex-specific growth in Ospreys: the role of sexual size dimorphism. Auk 110:900-910

Schmidt D (1999) Untersuchungen zur Populationsbiologie und Habitatnutzung des Fischadlers Pandion haliaetus in Deutschland. ILN-Werkstattreihe 6, Singen

Schmidt D (2001) Die Bestandsentwicklung des Fischadlers Pandion haliaetus in Deutschland im ausgehenden 20. Jahrhundert Vogelwelt 122:117-128

Schmidt D (2010) Der Brutbestand des Fischadlers Pandion haliaetus in Deutschland im frühen 21. Jahrhundert Charadrius 46:10-17

Shmueli M, Izhaki I, Zinder O, Arad Z (2000) The physiological state of captive and migrating Great White Pelicans (Pelecanus onocrotalus) revealed by their blood chemistry. Comp Biochem Physiol A 125:25-32

Smith EE, Bush M (1978) Hematologic parameters on various species of strigiformes and falconiformes. J Wildlife Dis 14:447-450

Steeger C, Ydenberg RC (1993) Clutch size and initiation date of ospreys: natural patterns and the effect of natural delay. Can $\mathbf{J}$ Zool 71:2141-2146

Steidl RJ, Griffin CR, Niles LJ (1991) Contaminant levels of osprey eggs and prey reflect regional differences in reproductive success. J Wildlife Manage 55:601-608
Stinson CH (1977) Growth and behaviour of young ospreys Pandion haliaetus. Oikos 28:299-303

Stinson CH (1978) The influence of environmental conditions on aspects of the time budgets of breeding ospreys. Oecologia $36: 127-139$

Tilgar V, Ots I, Mänd R (2004) Bone alkaline phosphatase as a sensitive indicator of skeletal development in birds: a study of the great tit nestlings. Physiol Biochem Zool 77:530-535

Tilgar V, Kilgas P, Mägi M, Mänd R (2008) Age-related changes in the activity of bone alkaline phosphatase and its application as a marker of prefledging maturity of nestlings in wild passerines. Auk 125:456-460

Toschik PC, Rattner BA, McGowan PC, Christman MC, Carter DB, Hale RC, Matson CW, Ottinger MA (2005) Effects of contaminant exposure on reproductive success of osprey (Pandion haliaetus) nesting in Delaware River and Bay, USA. Environ Toxicol Chem 24:617-628

Umminger B (1977) Relation of whole blood sugar concentrations in vertebrates to standard metabolic rate. Comp Bioschem Physiol A 56:457-460

Van Daele LJ, Van Daele HA (1982) Factors affecting the productivity of Ospreys nesting in West-Central Idaho. Condor 84:292-299

Van Wyk E, Van der Bank H, Verdoorn GH (1998) Dynamics of haematology and blood biochemistry in free-living African whitebacked vulture (Pseudogyps africanus) nestlings. Comp Biochem Physiol A 120:495-508

Vergara P, Fargallo JA, Martínez-Padilla J (2010) Reaching independence: food supply, parent quality, and offspring phenotypic characters in kestrels. Behav Ecol 21:507-512

Villegas A, Sánchez JM, Costillo E, Corbacho C (2002) Blood chemistry and haematocrit of the black vulture (Aegypius monachus). Comp Biochem Physiol A 132:489-497

Viñuela JM, Ferrer M, Recio F (1991) Age-related variations in plasma levels of alkaline phosphatase, Calcium and inorganic phosphotus in chicks of two species of raptors. Comp Biochem Physiol 99:49-54

Weber M, Schmidt D, Hädrich J (2003) Chlororganische Rückstánde in Eiern des Fischadlers (Pandion haliaetus) aus Deutschland. J Ornithol 144:45-58

Wink M, Sauer-Gürth H (2000) Advances in the molecular systematics of African raptors. In: Chancellor RD, Meyburg BU (eds) Raptors at risk: proceedings of the V World Conference on Birds of Prey and Owls, Midrand, Johannesburg, South Africa 1998. WWGBP \& Hancock House, Berlin, pp 135-147

Wolf SH, Schreiber RW, Kahama L, Torres JJ (1985) Seasonal, sexual and age-related variation in the blood composition of the Brown Pelican (Pelecanus occidentalis). Comp Biochem Physiol A $82: 837-846$ 